\title{
Primary Text Distortions in Modern Archeographic Publications in Art History Evidence From Articles by Mikhail Gnesin
}

\begin{abstract}
Sergey Anikienko, ${ }^{1, *}$
${ }^{1}$ Department of Music Studies, Musical Composition and Methods of Musical Education of the Conservatory at Krasnodar State Institute of Culture, Krasnodar, Russia

"Corresponding author. Email: anikienko1966@mail.ru

ABSTRACT

Numerous recent publications of materials from Mikhail Gnesin's journalistic legacy that date back to the 1910s reveal a new page in creative activities by this outstanding musician. At the same time, annoying errors and misprints in archeographic publications (note that it applies to materials published at that time, not to handwritten ones) do not allow for a high-quality comprehensive historical and theoretical analysis of the text of these articles. A significant change in the original author's text often results in a direct meaning distortion.

In this view, we have identified a few deformity groups. First of all, these are omissions of individual words, phrases, and even sentences in general. A number of alterations occur due to incorrect endings reproduction. Merging a number of paragraphs into a single one violates the article structure and its logics. There is also a mere "conjecturing" of impaired author's text, even in cases when it can be restored from other sources.
\end{abstract}

Keywords: archeography, author's text, music journalism, Mikhail Gnesin, mass media, art criticism, structural text analysis

\section{INTRODUCTION}

In art studies, the latest researchers' interest is focused more and more on historical sources. It has become a trend to involve in the archeographic process, along with archival documents, the materials published in the late XIX - early XX century in the Russian media.

In Soviet times, archeographic publications were regulated by "Rules for Publishing Historical Documents in the USSR" (1990) [1] that allowed certain simplifications, especially while preparing popular scientific and educational publications. Scientific publications were intended for scientific research, while the purpose of popular scientific publications was to spread historical knowledge and to popularize historical documents among a wide range of readers [2].

So far, due to cancellation of all standard regulations approved in the USSR, this document, most likely, has lost its legal effect. However, the principles of historical document preparation for publication comprised in them remain valid in practice.
Meanwhile, our analysis of not only scientific works, but also popular scientific publications on art studies of recent years, directly or indirectly related to source studies and textual studies problems, has enabled us to identify a problem that has not yet found its resolving in methodological and theoretical works. However, its topicality is of no doubt. As a result of careless, sometimes even unscientific approach of researchers to author's text, there is a significant distortion of the original text in modern publications of historical documents. Not only the text of the author is distorted, but even its title and dating.

We encountered a whole complex of such author's text distortions while preparing for publication some selected articles by Mikhail Gnesin published in local periodicals of the early 1910s [3].

\section{ARTICLES BY MIKHAIL GNESIN IN LOCAL PERIODICALS OF THE 1910S}

The composer Mikhail Gnesin (1883-1957) belongs to the cohort of Russian musicians for whom the actual musical creativity was inseparable from literary and music critical activities. After graduating from St. 
Petersburg Conservatory (composition class of Nikolai Rimsky-Korsakov), his life and work for almost a decade and a half was associated with working in province: at the beginning at the Music School of Ekaterinodar Department of Imperial Russian Musical Society (1911-1913), then - from 1913 to 1921 - in his native Rostov-on-Don

His first experience in journalistic activity dates back to 1909: the article "On Gypsy romance" was published in St. Petersburg. In the future, Gnesin, while staying in province, continues to cooperate with press in the capital - magazines "Music" and "Musical Contemporary". However, in terms of musical education, the most demanded was for the composer his cooperation with the local press: in Ekaterinodar newspapers ("Kubansky Krai") and Rostov-on-Don ("Priazovsky Krai" and "Rostovskaya Rech") in 19131916. We revealed more than 40 articles by Gnesin. At the same time, in quantitative terms, chronologically they are distributed quite unevenly - from individual materials in the first years to extensive journalistic activity in 1916

It suggests that the composer did not immediately come to the idea of possibility of musical propaganda via provincial printed media: at that period, there was no such experience in Russian music journalism beyond the press of St. Petersburg. As we have already mentioned [4], musical enlightenment was still in its infancy in provincial press of the early twentieth century. At the same time, as noted by Ira Petrovskaya, in newspapers of any city, "representatives of various social groups, including professional musicians, wrote about music" [5].

It is worth mentioning a wide variety of issues discussed in Gnesin's articles within this period. Most of works deal with music history. These are not only memoir articles (about Alexander Scriabin, Anatoly Lyadov, etc.), obituaries (to Liverius Sacchetti and Max Reger) or dedicated to death anniversaries of Russian composers (Modest Mussorgsky, Anton Arensky), but also materials about works by Nikolai RimskyKorsakov (overture "Light Holiday", opera "Christmas Eve"), etc. Gnesin also deals with music and concert activities in the province and music education issues. In announcements for the upcoming concerts, Gnesin gives quite a detailed information about activities of a particular performer. Besides, the author pays attention to ballet and choreography (in particular, to creative activities by Mikhail Fokin), to history of theatrical art.

The most important feature of his style is engaging a lot of extensive quotations from publications by musicians and philosophers: "Chronicle of my musical life" by Nikolai Rimsky-Korsakov, articles by Vladimir Stasov, Herman Laroche, Nikolai Kashkin, Andrey Famintsyn, letters by Anatoly Lyadov, works by Immanuel Kant, Dmitry Pisarev, etc.
A significant number of publications were signed with the full name: M. Gnesin, M. F. Gnesin or Mikhail Gnesin, some articles were signed with cryptonyms $M$. $G$. or $M . F . G$., one work has the signature $M . G-n$.

Gnesin's articles are considered in more detail in our research [6].

At present, periodicals in which Gnesin's articles were published are bibliographic rarities; they have been preserved only in newspaper collections of the largest libraries in Moscow and St. Petersburg. Newspapers' preservation is satisfactory. Textual processing of materials published in them does not cause any noticeable difficulties. However, the print quality does not always allow you to read some individual words quire clearly. In addition, there are some text losses.

\section{HISTORIOGRAPHY OF MIKHAIL GNESIN'S PUBLICATIONS (CONTEMPORARY HISTORY)}

Gnesin's musical and critical legacy, especially dating to the pre-revolutionary period, is one of the unexplored aspects of composer's life and work. Most of his literary works remain unknown to a wide range of readers and researchers. Therefore, introduction of Gnesin's journalistic materials into scholarly discourse is an important advancement in Russian musicology.

Since 1999, a number of archeographic publications of archival documents (letters, memoirs) and individual publicistic works of the composer have appeared in scientific and popular literature. Above all, researchers sought for handwritten documents published during Gnesin's lifetime or previously deciphered manuscripts. Note that most of Gnesin's manuscript sources, due to complexity of their deciphering, have not been included in study areas yet.

The first in history of Russian musicology archeographic publication of Gnesin's music-critical works was the article "Rachmaninoff as Scriabin's performer" [7] ("Priazovsky Krai", October 18, 1915). Prepared by a local historian Vladimir Sidorov, this publication did not pursue scientific goals, but was a literary illustration for an essay about Gnesin's activities in Rostov-on-Don in Rostov History Encyclopedia.

In 2008, Gnesin's article "Mikhail Shchepkin and new trends in stage technique" ("Priazovsky Krai", November 01, 1916) was published in documents' collection "Vsevolod Meyerhold and Mikhail Gnesin" [8] compiled by Irina Krivosheeva and Sergei Konaev. The publication was dedicated to search and discoveries by Gnesin to mold the method of "musical realism" developed by film producer Vsevolod Meyerhold.

At various times, the whole set of nine articles by Gnesin published in Rostov press in 1915-1916 was reproduced in publications by Galina Sycheva. Later, 
all of them were combined in the study "Enlightenment in composing, social, scientific, pedagogical and publicistic activities of Mikhail Gnesin" [9]

Therefore, 11 of articles by Gnesin that had been published in the local periodical press in the 1910s were reproduced in various scientific and popular publications. They are not only a historical document, but also an important step in understanding literary and critical works by the composer.

Comparison of the text of these publications with the original source evidenced that all of them in one way or another did not avoid textual errors, inaccuracies and distortion of the text. At the same time, in some cases, the meaning of what is said is distorted to a complete opposite. In addition, when reprinting, there are errors not only in articles' titles, but also in the dates of their original publication. It prevents from a high-quality comprehensive historical and theoretical text analysis.

\section{MIKHAIL GNESIN AUTHOR'S TEXT AND ITS DISTORTIONS IN MODERN SCIENTIFIC TRANSCRIPTION}

Our research of publications made by modern scientists of Mikhail Gnesin's musical and critical works facilitates revealing several groups that distort the original author's text.

First of all, these are omissions of individual words, phrases, and even whole sentences that were not marked appropriately in modern texts. For example, in Gnesin's article "Mystery of humanity and music history. (From memoirs about Alexander Scriabin") in the phrase "Vot chem ob"yasnyayetsya besplodiye indo-arabskogo muzykal'nogo geniya, apatichno vzrashchivayushchego $v$ techeniye tysyacheletiya vso te zhe svoi makhrovyye tsvety" ("It explains the infertility of Indo-Arabic musical genius, apathetically nurturing for a thousand years its unchangeable polypetal flowers $)^{1}$ when reprinted, the italicized participial construction disappeared, and the word "genia" ("genius") was changed into "peniya" ("singing") [10] (probably as a result of computer text recognition: Cyrillic letters " 2 " and " $n$ " have similar graphics). As a result, it turns out that not the achievements of folk Arabic music are meant, but musical singing (which is a speech redundancy not characteristic of this highly educated author).

In the review "Musical Rostov in 1915", when reprinted, the phrase $"<\ldots>$ byli i pomimo kvarteta interesnyye vystupleniya: $v$ stenakh muzykal'nogo uchilishcha IRMO prokhodili sol'nyye vystupleniya $\mathrm{i}$ ansambli (sonatnyye vechera i t. d.)" ("< ... > besides are in italics. the quartet, there were other interesting performances: solo performances and ensembles (sonata evenings, etc.) were held within the walls of the Music School of Rostov-on-Don Department of Imperial Russian Musical Society") loses mentioning the educational institution and solo performances [11].

Word omissions of author's text often lead to meaning modification of what was said to the exact opposite. For example, the pathos of one fragment of the article "Olenina-d'Alheim" was Russian musician's dislike of Paris. "We must despise Paris," wrote Gnesin, "this wonderful laboratory of art". Instead, in modern reproduction of this text, there appeared the phrase "We need to go to Paris" [12], drastically crossing out all the above in the article.

The same group of author's text distortions includes arbitrary additions of individual words made by the author of modern publication. In the same reprinted version of Rostov-on-Don musical life, the author's genuine text reads: "i novaya shkola privlekla dostatochnoye kolichestvo uchashchikhsya, i prezhniye niskol'ko ne postradali" ("the new school engaged a sufficient number of students, and the former students were not impaired"); the reader of the reprinted version, however, finds an inappropriate repetition of the language unit: "i novaya shkola privlekla dostatochnoye kolichestvo uchashchikhsya, i prezhnyaya shkola niskol'ko ne postradala" ("both the new school has engaged a sufficient number of students, and the former school was not impaired a bit") [13], as well as the change of the grammatical category that expresses the quantitative characteristic of the subject.

Also, the modern reprints of Gnesin's articles are characterized by pseudo-synonymic substitutions that distort the text to a considerable extent. For example, in the publishing "Musical Rostov in 1915" quoted by us above, Reinhold Glier's youth symphony turns from "attractive" to "fascinating" [14]; and in the article about Alexander Scriabin, "The mystery of humanity and the history of music", in the phrase "po odnim lish' ukrasheniyam nemyslimo konstruirovat' samyye sooruzheniya" ("it is unthinkable to design the major structures based on ornaments alone"), the last words were changed to "sami sooruzheniya" ("the structures as such") [15], and it radically changes the meaning of what was said.

One more example also describes a similar semantic deformity of the source text. In the same article, touching upon the influence of Kiev Conservatory evacuated to Rostov-on-Don during the World War I on activities of local city music schools, Gnesin writes about a local music school: "<..> neuzheli $z h$ ucheniki tak seychas i razbegutsya iz nego" ("<...> are the students really going to run away from it (= from the school) now?"). In modern transcription, the meaning is distorted to absurd after omission of a Russian particle 
enhancing emotional sense of the phrase (are...really) and replacement of the preposition of direction from it by the preposition of cause "due to": "<..> neuzheli ucheniki tak seychas i razbegutsya iz-za nego" ("<...> are the students going to run away due to it (= because of the Conservatory) now") [16].

Another type of author's text distortion occurs because of wrong reproduction of word endings. For example, in the article "Olenina-d'Alheim" "the fate of Mussorgsky's posthumous successes outlined ... schematically" in the new edition becomes " $a$ schematic fate" [17]. In the above fragment about the negative attitude of a Russian musician to Paris, Gnesin calls for "disdaining for light laurels of refined residents of capitals", referring to both capitals of the Russian Empire - Moscow and St. Petersburg. Wording of the modern text is perplexing by mentioning just one capital [18]: it is unclear which is referred to, Paris or Russia, and if Russia is meant, why is the capital only one?

In some cases, there is also "conjecturing" of impaired author's text, even in cases when the text can be restored from other sources. A good example is "a possible version of author's words" ${ }^{2}$ used while preparing the publication of article "Anton Arensky" instead of the lost newspaper text. In this case, we are talking about a quote from the book by Nikolai Rimsky-Korsakov "Chronicle of my musical life", that is not, as it is known, a bibliographic rarity. As a result of this rather free approach to the author's text, the sentence "Vokal'naya yego muzyka dazhe okazalas' sposobnoy vliyat' na boleye molodykh kompozitorov" ("His vocal music was even able to influence younger composers") turned into a heavy verbal structure that lost its semantic meaning: "[Arenskiy obladal darovitost'yu], sposobnoy vliyat' na boleye molodykh kompozitorov" ("[Arensky had a gift] that could influence younger composers") [19].

In modern reproductions of Gnesin's articles, there often occurs so-called punctuation replacement when punctuation marks are substituted. This is most often the case when Gnesin uses complex and compound sentences. While preparing such publications for printing, authors often break such sentences into several independent ones. Here is an example from the article "Modest Petrovich Mussorgsky". Author's text: "Mussorgsky's seriousness in his attitude to art, his creative concentration and absolutely exceptional musical talent are undeniable, and now <...> they can no longer inspire an attitude to them different from adoration" is divided into two independent sentences: "Mussorgsky's seriousness $\langle\ldots\rangle$ and absolutely exceptional musical talent are undeniable. And they can

his actions. no longer generate a different attitude to them $\langle\ldots>$ " [20]. In the article-memoirs of Scriabin the sentence: "The divine "truth" of music was definitely given to humanity at once; but not being able to grasp it, the humanity rejected it or lost it having clung to the simplest and most evident things; but after a millennial thrust of creative work at this simple thing, the humanity has finally arrived to knowledge of the truth, and this truth was found to be the one that was once given to humanity" was split into three independent sentences at re-publishing (splitting was done by punctuation mark ";") [21].

The same distortion type of author's text at republishing includes merging several paragraphs into a single one. Such means used by authors-compilers while preparing the primary source for publication violate the internal logic and the semantic structure of the primary source text. We should point out that the "Rules for Publishing Historical Documents" do not provide for such a scientific and critical facility of text rendering. On the contrary, it is allowed to split the text into paragraphs, as needed, but for informal documents [22].

\section{DISTORTIONS OF TITLES AND PUBLICATION DATES OF MIKHAIL GNESIN'S ARTICLES}

Distortion of the title and / or the publication date of the article refer to another set of deformities of author's text.

To errors in the title of a journalistic material we relate its simplification, when the author while preparing the text for publication or compiling a bibliographic list, omits a subtitle. Thus, the title "The Nymph. (For the concert of Nadezhda Zabela-Vrubel)" ("Kubansky Krai", March 27, 1913) in the lists of articles published by Gnesin was transformed into "The Nymph" [23]. Another case is "adding" elements nonexisting in the original text: the article "Performances of the Association of Russian Opera Artists" ("Rostovskaya Rech", March 16, 1916) was called "Performances of the Association of Russian Private Opera Artists" [24].

The most crucial, in our opinion, is distortion of surnames and activity areas of publication heroes in the title. For example, in the title of Gnesin's article "K priyezdu skazatel'nitsy Krivopolenovoy" ("For arrival of narratress Krivopolenova"), the author uses an obsolete word that is used only in Northern regions of the country. However, it describes the activity area of publication hero, Maria Krivopolenova - storytelling of old folk tales and epics. Meanwhile, the list of literary works by the composer comprises "skazitel'nica (the narrates) Krivopol'naya" [25]. 
The gravest factual errors include incorrect publication dating of some articles by Gnesin. For example, the article "Anti-semitism and music" ("Priazovsky Krai", July 24, 1916) in bibliographic lists of Gnesin's publications is dated by July, 1915 [26]. The publication date of the article "Society of people's universities in Rostov and musical art" ("Priazovsky Krai", July 31 and August 3, 1916) is related to 1917 [27].

\section{Distortions OF MIKHAIL GNESIN AUTHOR'S TEXT IN POPULAR SCIENCE LITERATURE}

In popular science literature, "the results of criticism $<\ldots>$ are reflected in textual notes" [28]. However, analysis of popular scientific publications that archaographically reproduce the texts of Gnesin's articles revealed that this publication category is generally characterized by the same set of deforming groups.

Thus, when the article "Rachmaninoff as Scriabin's performer" was re-published, author's description of Rachmaninoff's music as "elegically tuned" was transformed into "epically tuned" [29]. And Scriabin's "strivings" in the creative process turned into "undertakings" [30]. A pseudo-synonymic replacement of the verb "was" with another one, but of different time reference "will" brings the events discussed in the original source into the past: "The upcoming week was to be an echo of "Scriabin's Week" that had just been over in both capitals" [31].

In popular science publications, there is also a merging of text paragraphs and punctuation replacement resulting in splitting a complex sentence into several simple ones.

\section{CONCLUSION}

Thus, the original source text distortion during its archeographic processing in modern publications in art history revealed by us at the example of Mikhail Gnesin's articles is a major scientific problem. After all, in research work, it is not always possible to reach author's text directly. This way, the material published in a scientific or a popular scientific paper is perceived as the only true and accurate one.

In our opinion, negligence in preparation for publishing of art studies historical document is catered by insufficient professional training of academic staff at initial stages of their education (Bachelor's and Master's degrees). For example, in recent years, such subjects as "Source studies", "Textual studies", and "Archival and bibliographic practice" have been excluded from the curricula of musicologists at some musical higher education institutions.
Moreover, researchers, most likely heavily relying on modern computer technologies of text recognition, do not pay enough attention to careful comparative checking with the text of the original source at the final stage of a historical document preparation for publication. No doubt, it is just poor attention to detail.

However, finally, the responsibility for accuracy of author's text reproduction lies on the researcher who prepared the text for publication.

\section{References}

[1] Rules for Publishing Historical Documents in the USSR. Moscow, 1990

[2] Ibid, p. 3-4.

[3] S. V. Anikienko, G. Yu. Ertsengel, comp., prep. for publ., comment. "Unknown Mikhail Gnesin: articles from provincial press of the 1910s". Krasnodar, Krasnodar State Institute of Culture, 2020

[4] S. V. Anikienko. "Newspaper "Kuban Regional Vedomosti": birth of musical enlightenment (1890s)" / Music in the media culture space. Krasnodar, Krasnodar state Institute of culture, 2019, p. 196-199.

[5] I. F. Petrovskaya. "Source studies of the history of Russian musical culture of the XVIII - early XX century". Moscow, Music, 1983, p. 179.

[6] S. V. Anikienko, G. Yu. Ertsengel. "Cogitating musician musical and critical articles by M. F. Gnesin in the provincial periodical press of the 1910s" / Bulletin of Tomsk State University. Cultural studies and art criticism, 40, 2020.

[7] V. S. Sidorov. Encyclopedia of old Rostov and Nakhichevanon-Don, Vol. 5. Rostov on-Don, Gefest, 1999, pp. 73-79.

[8] I. V. Krivosheeva, S. A. Konaev, comp. Vs. Meyerhold and Mich. Gnesin. Moscow, RATI-GITIS, 2008, p. 55-59.

[9] G. S. Sycheva. "Enlightenment in Mikhail Gnesin's compositional, social, scientific, pedagogical and publicistic activities", Dissertation for PhD in Art Criticism. Rostov-onDon, 2013.

[10] Ibid, p. 303.

[11] Ibid, p. 328.

[12] Ibid, p. 271.

[13] Ibid, p. 327.

[14] Ibid, p. 328.

[15] Ibid, p. 302.

[16] Ibid, p. 327.

[17] Ibid, p. 270.

[18] Ibid, p. 271.

[19] Ibid, p. 296.

[20] Ibid, p. 287.

[21] Ibid, p. 300.

[22] Rules for Publishing Historical Documents in the USSR, p. 21.

[23] G. S. Sycheva. Spec. ed., p. 217.

[24] Ibid, p. 219.

[25] Ibid, p. 219.

[26] Ibid, p. 277.

[27] Ibid, p. 219, 319.

[28] Rules for Publishing Historical Documents in the USSR, p. 21.

[29] V. S. Sidorov. Spec. ed., p. 74.

[30] Ibid, p. 75

[31] Ibid, p. 73. 